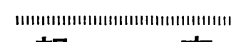

報文

\title{
In Vitro におけ当殺虫剤の連合作用
}

\author{
大井正典, 本山直樹 \\ 千葉大学園芸学部環境生物学研究室
}

(平成 3 年 1 月 21 日受理)

\section{In Vitro Studies on Joint Action of Insecticides}

\author{
Masanori Or and Naoki Motoyama \\ Laboratory of Environmental Biology, Faculty of Horticulture, \\ Chiba University, Matsudo, Matsudo 271, Japan
}

\begin{abstract}
In vitro studies were carried out to substantiate the result obtained from theoretical analysis that the level of potentiation produced by joint action of insecticides could be predicted by using such parameters as the affinity of each insecticide to the degradation enzyme involved, the rate of degradation, and the $I_{50}$ for target inhibition in the presence of the degradation enzyme. These parameter values were determined in a simple model system that consists only a single enzyme for degradation, carboxylesterase from the porcine liver, and the target for inhibition AChE from the electric eel. The results showed that a combination of malaoxon and paraoxon as well as malaoxon and dichlorvos among various combinations of insecticides evaluated fulfilled the conditions for potentiation satisfactorily. A comparison of $\mathrm{I}_{50}$ for AChE inhibition actually demonstrated a high level of potentiation with the above two combinations. Furthermore, the mixing ratio of two insecticides which produced the maximum potentiation level was equal to the ratio of $I_{50}$ of individual insecticides. These results were in agreement with what the theoretical analysis by computer simulation suggested.
\end{abstract}

\section{緒言}

わが国では種々の目的のために殺虫剤の混用が広く実 施されている．混用によって得られる連合作用の理論的 解析に関しては, 連合作用の大きさを数量的な理論に基 づいて解析した例はあるものの1)，連合作用が生ずるよ らな条件を理論的に解析した例はなかった，前報りにお いて，著者らは薬物速度論的な手法を用いることによっ て, 連合作用を生むための条件を理論的に明らかにし た.すなわち, AChE 阻害剤の組合せを仮定し, 作用点 と解毒酵素の久が含まれる単純なモデルを用いてコンピ ュータシミュレーションを行なった. その結果, 組み合 わせた 2 薬剤が解毒酵素を拮抗的または非拮抗的に阻害 し合うような場合には, 殺虫剤の連合作用の大きさは組 久合わせた扮の特のの殺虫剤の解毒酵素に対する親和性
$(K m)$ と最大解毒速度 $(V)$ ，执よび解毒酵素を含んだ 条件での作用点阻害の $I_{50}$ によって予測できることを示 した。また，その場合最も相乗作用の大きくなる二つの 薬剤の混合比は理論的には $I_{50}$ の比に等しいということ を明らかにした. 本研究の目的は, このような理論的解 析の結果を in vitro の実験によって証明することであ る. そのために，作用点としてアセチルコリンェステラ 一ゼ (AChE), 解毒酵素としてカルボキシルェステラー ゼ $(\mathrm{CE})$ を含む in vitro の系をモデルとして実験を行な った.

\section{材料と方 法}

\section{1. 試 薬 類}

IBP ( $S$-benzyl $O, O$-diisopropyl phosphorothioate) (純 度 90\%）はクミアイ化学工業株式会社から, マラチオン 
( $S$-1,2-bis(ethoxycarbonyl)ethyl $O, O$-dimethyl phosphorodithioate）（純度 $95.4 \%$ ）は住友化学工業株式会社よ り提供していただいた工業用原体をそのまま用いた。そ の他の試薬および酵素についてはすでに報告3)したとお りであり，AChEは電気うなぎから精製されたもの (Sigma 社製, タイプIII, $950 \mathrm{unit} / \mathrm{mg}$ タンパク), CE は ブタ肝蔵から精製されたもの（Sigma 社製，タイプ I, 230 または 335 unit/mg タンパク）を用いた.

\section{CE の阻害}

阻害実験は前報了) に述べた方法に従って，パラニトロ フェニルブチレート（ $p \mathrm{NPB})$ を基質として行ない，解 離定数 $K_{\mathrm{d}}$, アシル化（リン酸化またはカルバミル化） 定数 $k_{2}$, 打よび脱アシル化定数 $k_{3}$ を求めた. な拈，反 応液の組成は, $30 \mathrm{mM} p \mathrm{NPB}$ アトン溶液 $10 \mu \mathrm{l}$, 各濃 度の阻害剤のアセトン溶液 $50 \mu \mathrm{l}, 0.1 \mathrm{M}$ リン酸緩衝液 (pH 8.0) $2990 \mu \mathrm{l}, 0.17 \mathrm{unit} / \mathrm{ml}$ の酵素液 $20 \mu \mathrm{l}$ である. 基質の濃度は $\mathrm{CE}$ に対しては基質に対する $K m$ 值 $(76.2$ $\mu \mathrm{M})$ よりやや大きくとった. 阻害剤の濃度は $K_{\mathrm{d}}$ 付近 で数段階とった. どの阻害剤を用いた場合も $k_{2} \gg k_{3}$ で

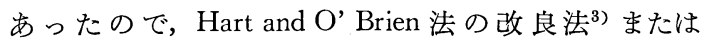
1/B〜1/[I] プロット ${ }^{3,4}$ （ $B$ は酵素活性の減少の大きさ を表わし，[I] は阻害剤濃度と同様の次元をもつ）を用 いて各パラメータを求めた。 な特カルバリルについては $k_{3}$ がすでに知られているので3), この值を $1 / B \sim 1 /[\mathrm{I}]$ プ ロットに代入し他のパラメータを求めた.

\section{AChE の阻害}

Main and Dauterman ${ }^{5)}$ の方法を用い，アセチルチオ コリン（ATCh）を基質として, AChE 阻害の 2 分子速 度定数 $\left(k_{\mathrm{i}}\right)$ を求めた. 反応液の組成と手順は前報 ${ }^{3)}$ に 述べた方法と同様である，ただし，この方法では阻害剤 濃度が $K_{\mathrm{d}}$ より十分に小さいといら条件が必要なので, コントロール活性と阻害剤の存在下に拉ける活性の初期 值が等しくなるように阻害剤濃度を設定した。

\section{4. 解毒酵素の存在下における AChE 阻害の $I_{50}$ の} 測定

解毒酵素である $\mathrm{CE}$ の存在下における $\mathrm{AChE}$ 阻害の $\mathrm{I}_{50}$ 值は，前阻害の後に基質を加えて AChE の残存活性 を調ベ，プロビット法により算出した．前阻害時の反応 液組成は, 各濃度の阻害剂のアセトン溶液が $50 \mu \mathrm{l}$, $\mathrm{AChE}$ (10 unit $/ \mathrm{ml})$ が $20 \mu \mathrm{l}, \mathrm{CE}(151$ unit $/ \mathrm{ml})$ が 100 $\mu 1,0.1 \mathrm{M}$ リン酸緩衝液 ( $\mathrm{pH} 8.0$ ) が $2830 \mu \mathrm{l}$ である. $37^{\circ} \mathrm{C}$ で 1 時間前阻害した後, $0.02 \mathrm{M}$ の ATCh と 0.02 M の DTNBを拈の拉の $100 \mu 1$ ずつ反応液に加えて直 ちに攪拌し，分光光度計を用いて $412 \mathrm{~nm}$ に拉ける吸光 度の変化を測定した。

\section{結果と考察}

Table 1 には，一連の化合物による CE 阻害反応のパ ラメータ, すなわち, 酵素-阻害剤の可逆的複合体形成 の親和性を表わす解離定数 $K_{\mathrm{d}}$, アシル化定数 $k_{2}$, 脱ア シル化定数 $k_{3}$ の各值，およびアシル化と脱アシル化の

Table 1 Kinetic constants of carboxylesterase inhibition with various inhibitors.

\begin{tabular}{lcccc}
\hline Inhibitor & $\begin{array}{c}K_{\mathrm{d}} \\
(\mu \mathrm{M})\end{array}$ & $\begin{array}{c}k_{2} \\
\left(\mathrm{~min}^{-1}\right)\end{array}$ & $\begin{array}{c}k_{3} \\
\left(\mathrm{~min}^{-1}\right)\end{array}$ & $\begin{array}{c}\left.K m^{\mathrm{a}}\right) \\
(\mu \mathrm{M})\end{array}$ \\
\hline Paraoxon & $\left.0.702^{\mathrm{a}}\right)$ & 0.660 & 0.0272 & 0.0278 \\
DEF & 0.428 & 0.563 & 0.0739 & 0.0497 \\
Dichlorvos & 0.251 & 0.297 & 0.129 & 0.0760 \\
Carbaryl & 14.3 & 0.548 & 0.0263 & 0.655 \\
IBP & $(2.4)^{\mathrm{b})}$ & $(0.082)$ & & 1.63 \\
Propoxur & 71.6 & 1.93 & 0.0451 & 2.34 \\
Metolcarb & $(16.6)$ & $(0.55)$ & $(0.0173)$ & 6.13 \\
Malathion & 20.4 & 0.344 & 0.0445 & 11.1 \\
Methomyl & 46.2 & 0.289 & 0.0442 & 13.2 \\
Malaoxon & 76.6 & 0.0439 & 0.00741 & 31.9 \\
Pirimicarb & $(5.3)$ & $(0.0017)$ & $(0.00156)$ & 80.8 \\
\end{tabular}

a) $K m=K_{\mathrm{d}} \times k_{3} /\left(k_{2}+k_{3}\right)$.

b) Data without standard deviation are from the previous paper. ${ }^{3)}$

c) Values in parenthesis show standard deviation. 
速度が等しい定常状態における見かけの親和性を表わす $K m$ 值 $\left(K m=K_{\mathrm{d}} k_{3} /\left(k_{2}+k_{3}\right)\right)^{6)}$ を示した. なお，括弧 内に標準偏差を伴った值は本研究において求めた值であ り，標準偏差を伴っていない值は前報 ${ }^{3)}$ より引用した。 これらの值を薬剤間で比較すると, とくに $K_{\mathrm{d}}$ と $K m$ に 関しては薬剤間で大きく值が異なった. ジクロルボス， DEF およびパラオクソンは $K_{\mathrm{d}}$ と $K m$ が小さく, 反応 初期の可逆的複合体の形成と定常状態に拈ける親和性が 高いことが示された. 一方，メソミルとピリミカルブは 反応初期の可逆的複合体の形成に拈ける親和性が小さ く, マラオクソンとピリミカルブは定常状態における親 和性が小さかった。 また， $k_{2} や k_{3}$ 值の薬剤間の違いは $K_{\mathrm{d}}$ や $K m$ 值と比較して小さかった. マラチオンなどの チオノ体による CE のリン酸化は起こりにくいにもかか わらず，マラチオンは CE に対してわずかな阻害活性を 示した. この理由は不明であるが，もし，iso-マラチオ ン7)が不純物として混在していれば, この化合物が CE 阻害の原因であるかもしれない. マラチオンによって阻 害された $\mathrm{CE} の k_{3}$ 值は他の阻害荗と比較して小さかっ た.

AChE に対する阻害力を示すパラメータとして測定 した 2 分子速度定数 $k_{\mathrm{i}}$ は, Table 2 に示した. DEF と IBP による AChE の阻害は認められなかった. $k_{\mathrm{i}}$ で判 断すると, AChE 阻害力の最も大きい化合物はマラオク ソンであり, メソミル, プロポクスル，パラオクソン, ジクロルボス, カルバリルの順で阻害カが小さくなっ た. $\mathrm{AChE}$ に対する $k_{\mathrm{i}}$ と CE に対する $k_{\mathrm{i}}\left(k_{\mathrm{i}}=k_{2} / K_{\mathrm{d}}\right)$ には相関関係を認めることはできなかった.

一連の阻害剂による $\mathrm{AChE}$ 阻害の $\mathrm{I}_{50}$ 值を $\mathrm{CE}$ の存 在下和よび非存在下に执いて調べた結果は Table 3 に示 した. CE の非存在下に括ける $\mathrm{I}_{50}$ 值は Table 2 に示す $k_{\mathrm{i}}$ 值から算出した. すなわち, Aldridge ${ }^{8)}$ の式 $\log _{10} P=$ $2-k_{\mathrm{i}}[\mathrm{CX}] t / 2.303$ ([CX] は阻害剂濃度を表わす) に $P($ 阻害度 $)=50 \%$ と $t$ (時間 $)=60 \mathrm{~min}$ を代入すると 60 分後に AChE を $50 \%$ 阻害するような阻害剤濃度を導き 出す式, 寸なわち $I_{50}=0.0116 / k_{1}$ の式が得られ， $I_{50}$ が 計算できる，各阻害剤の AChE 阻害に及ぼす CE の影 響の大きさは，CE の存在下と非存在下に括ける $\mathrm{I}_{50}$ の 比から予測できる.この比はマラチオンでは 37 倍で, マ ラオクソンでは 528 倍であり，他の化合物と比較しては るか大きかった．両化合物ともカルボキシルェステルが $\mathrm{CE}$ によって加水分解されるので9), CE はこれらの阻害 剂を解毒することによって AChE 阻害能力に大きな影 響を与えたといえる。他の阻害剤については，CE の存 在下と非存在下に护る $\mathrm{I}_{50}$ の比はマラチオンやマラオ
Table 2 Bimolecular rate constant of $\mathrm{AChE}$ inhibition.

\begin{tabular}{lc}
\hline Inhibitor & $k_{\mathrm{i}}\left(\mathrm{min}^{-1} \mathrm{~mm}^{-1}\right) \pm$ S.D. \\
\hline DEF & N.D. $\left.{ }^{\mathrm{a}}\right)$ \\
Dichlorvos & $24.8 \pm 1.5$ \\
Carbaryl & $20.0 \pm 2.2$ \\
IBP & N.D. \\
Propoxur & $57.7 \pm 1.8$ \\
Paraoxon & $37.9 \pm 2.1$ \\
Metolcarb & $2.16 \pm 0.16$ \\
Malathion & $1.14 \pm 0.041$ \\
Methomyl & $65.0 \pm 4.6$ \\
Malaoxon & $258 \pm 13$ \\
Pirimicarb & $0.431 \pm 0.040$
\end{tabular}

a) No detectable inhibition was observed under the experimental condition.

Table $3 \quad I_{50}$ of AChE inhibition with various inhibitors $^{\text {a) }}$ determined in the presence $(+\mathrm{CE})$ or absence $(-\mathrm{CE})$ of carboxylesterase $(\mathrm{CE})$.

\begin{tabular}{lccc}
\hline \multirow{2}{*}{ Inhibitor } & \multicolumn{2}{c}{$\mathrm{I}_{50}(\mu \mathrm{M})$} & Ratio \\
\cline { 2 - 3 } & $\left.-\mathrm{CE}^{\mathrm{b}}\right)$ & $+\mathrm{CE}$ & \\
\hline Paraoxon & 0.306 & 0.828 & 2.7 \\
DEF & $>1000$ & $>1000$ & N.D. \\
Dichlorvos & 0.468 & 2.93 & 6.3 \\
IBP & $>1000$ & $>1000$ & N.D. \\
Carbaryl & 0.580 & 1.10 & 1.9 \\
Propoxur & 0.201 & 0.471 & 2.3 \\
Metolcarb & 5.37 & 8.24 & 1.5 \\
Malathion & 10.2 & 380 & 37.3 \\
Methomyl & 0.178 & 0.253 & 1.4 \\
Malaoxon & 0.0487 & 25.7 & 528 \\
Pirimicarb & 26.9 & 64.7 & 2.4
\end{tabular}

a) AChE was preincubated with inhibitors for $1 \mathrm{hr}$ prior to the addition of the substrate, ATCh.

b) $\mathrm{I}_{50}$ in the absence of $\mathrm{CE}$ was calculated using $k_{\mathrm{i}}$ values listed in Table 2 according to the following equation: $\mathrm{I}_{50}=0.0116 / k_{\mathrm{i}}$.

クソンの場合よりもはるかに小さいが， $\mathrm{I}_{50}$ の差は明ら かに存在する，その中でとくにジクロルボスにおける $I_{50}$ の比が比較的大きかったのは, $I_{50}$ がもともと小さく 反応液中の濃度が小さかったことと, $k_{3}$ が大きいために (Table 1) CE によって解毒されるジクロルボスの割合 が多かったためと推察される，一方，他の化合物におい ては $I_{50}$ の比はいずれも 2 倍付近に集中した. CE の非 存在下に拉ける $I_{50}$ 值は $k_{3}=0$ を仮定して $k_{1}$ から計算 
したが，前阻害の時間が 1 時間と長いことから，CE 存 在拈よび非存在下に叔ける $\mathrm{I}_{50}$ の差は，阻害剂の解毒と いらょり脱アシル化によって生じた差と考えられる。さ らに，実際に $k_{3}$ を $0.02 \mathrm{~min}^{-1}$ と仮定して予備的にコン ピュータシミュレーションを行ない $I_{50}$ の值を求めたと ころ, 1 時間の前阻害では $I_{50}$ の比は約 2 倍となり上記 の推察を支持した.

殺虫剈の連合作用に関する理論的解析の結果 ${ }^{1)}$ によれ ば,連合作用の大きさは，組み合わせた薬剤を A， B とす ると,解毒酵素に対する薬剤の親和性を表わす Michaelis 定数（おの扔の $K_{\mathrm{A}}$ と $K_{\mathrm{B}}$ ）, 最大解毒速度（おのおの $V_{\mathrm{A}}$ と $\left.V_{\mathrm{B}}\right)$ 抌よび解毒酵素の存在下での AChE 阻害の $\mathrm{I}_{50}$ (おの括の $\mathrm{I}_{\mathrm{A}}$ と $\mathrm{I}_{\mathrm{B}}$ ）を用いて予測できる。すなわち， 相乗作用は $K_{\mathrm{B}} \ll K_{\mathrm{A}} \mathrm{I}_{\mathrm{B}} / \mathrm{I}_{\mathrm{A}}, \quad V_{\mathrm{B}} \ll V_{\mathrm{A}} \mathrm{I}_{\mathrm{B}} / \mathrm{I}_{\mathrm{A}}$ かつ $K_{\mathrm{B}} \ll \mathrm{I}_{\mathrm{B}}$ の 場合に発揮される。本研究では実際に各阻害剂に対する $\mathrm{CE}$ の $V$ の值を求めなかったが，マラチオンとマラオク ソンに関してのみ $\mathrm{CE}$ の存在下と非存在下に拈ける $\mathrm{I}_{50}$ に大きな違いがあったので (Table 3)，これらの阻害剤 は他の阻害剤と比較してはるかに $V$ の值が大きいと考 えられる.したがって，マラチオンまたはマラオクソン を阻害剤 $\mathrm{A}$ となせば, $V_{\mathrm{B}} \ll V_{\mathrm{A}} \mathrm{I}_{\mathrm{B}} / \mathrm{I}_{\mathrm{A}}$ の条件が満たされ るような阻害剂 $\mathrm{B}$ との組合せは多いと考学られる。また， この条件に加えて， $K_{\mathrm{B}} \ll K_{\mathrm{A}} \mathrm{I}_{\mathrm{B}} / \mathrm{I}_{\mathrm{A}}$ と $K_{\mathrm{B}} \ll \mathrm{I}_{\mathrm{B}}$ の条件を十 分に満たしている阻害剤 $\mathrm{B}$ 汪ど相乗作用が大きいことに なる、ただしこの場合の阻害はアシル化を伴うので阻 害剂の解毒酵素に対する親和性は，阻害の進行とともに 反応開始直後に括沙る阻害剂と酵素の解離定数 $\left(K_{\mathrm{d}}\right)$
から定常状態に打けるみかけの親和性 $(K m)$ に変化す る。皇こで, 親和性が $K_{\mathrm{d}}$ である場合と $K m$ である場合 のそれぞれで相乗作用をもたらす組合せを検討してみ た. Table 4 ではマラオクソン(阻害剤A)を他の阻害剤 （阻害剂 B）と組み合わせた場合，Table 5 ではマラチオ ン(阻害剤 $\mathrm{A}$ )を他の阻害剤(阻害剂 $\mathrm{B})$ と組み合わせた場 合の連合作用の大きさを予測した結果を示した.ただし， $K m_{\mathrm{A}}, K_{\mathrm{d}_{\mathrm{A}}}, \mathrm{I}_{\mathrm{A}}$ は打の扮の阻害剤 $\mathrm{A} の K m, K_{\mathrm{d}}$, 拈よ び $\mathrm{CE}$ 存在下での $\mathrm{I}_{50}$ を表わす. $K m_{\mathrm{B}}, K_{\mathrm{d}_{\mathrm{B}}}, \mathrm{I}_{\mathrm{B}}$ は掞の おの阻害剤 $\mathrm{B}$ の $K m, K_{\mathrm{d}}$, 拈よび $\mathrm{CE}$ 存在下での $\mathrm{I}_{50}$ を 表わす $\left(K m\right.$ と $K_{\mathrm{d}}$ は Table $1, \mathrm{I}_{50}$ は Table 3 に記載).

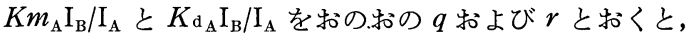
$K m_{\mathrm{B}} / q$ および $K_{\mathrm{d}_{\mathrm{B}}} / r$ が小さいほど $K_{\mathrm{B}} \ll K_{\mathrm{A}} \mathrm{I}_{\mathrm{B}} / \mathrm{I}_{\mathrm{A}}$ の条 件を満たすことになり，相乗作用が大きいことを示唆す る. その結果，マラオクソンをマラチオン，ジクロルボ スまたはパラオクンンと組み合わせた場合に $K m_{\mathrm{B}} / q$ 打 よび $K_{\mathrm{d}_{\mathrm{B}}} / r$ の值が共に小さかった (Table 4). またこれ らの薬剤のなかで, ジクロルボスが $K m_{\mathrm{B}} \ll \mathrm{I}_{\mathrm{B}}$ と $K_{\mathrm{d}_{\mathrm{B}}} \ll \mathrm{I}_{\mathrm{B}}$ の両方, マラチオンとパラオクソンは $K m_{\mathrm{B}} \ll \mathrm{I}_{\mathrm{B}}$ といら条 件を満たしていた。したがって，これらの組合せに执い て相乗作用が大きくなることが予測される。一方，マラ チオンと他の阻害剤を組み合わせた場合は $K m_{\mathrm{B}} / q$ と $K_{\mathrm{d}_{\mathrm{B}}} / r$ の值は 1 より大きいものが汪とんどで，相乗作用 は小さいことが予測された(Table 5)。DEF や IBPを混 合した場合の相乗作用についてはとくに検討しなかっ た。これらの阻害剈は AChE に対する阻害能力がない ので，これらの濃度を上げるほど相乗作用が大きくなる

Table 4 Parameters for the evaluation of potentiation level produced by a joint action of malaoxon (inhibitor A) combined with various other compounds (inhibitor B).

\begin{tabular}{lcccc}
\hline & \multicolumn{3}{c}{ Parameter } \\
\cline { 2 - 4 } Inhibitor & $K m_{\mathrm{A}} \mathrm{I}_{\mathrm{B}} / \mathrm{I}_{\mathrm{A}}$ & $K m_{\mathrm{B}} / q$ & $K_{\mathrm{dA}} \mathrm{I}_{\mathrm{B}} / \mathrm{I}_{\mathrm{A}}$ & $K_{\mathrm{d} \mathrm{B}} / r$ \\
\hline Malathion & $(q)$ & 0.0234 & 1217 & 0.0629 \\
Paraoxon & 472 & 0.0276 & 2.65 & 0.327 \\
Dichlorvos & 1.03 & 0.0283 & 9.38 & 0.0314 \\
Carbaryl & 3.64 & 0.479 & 3.52 & 4.06 \\
Metolcarb & 1.37 & 0.517 & 26.4 & 1.52 \\
Malaoxon & 10.2 & 1 & 82.3 & 2.29 \\
Pirimicarb & 31.9 & 1.01 & 207 & 13.5 \\
Propoxur & 80.3 & 3.99 & 0.810 & 1112 \\
Methomyl & 0.585 & 42.2 & 0.51 & 1 \\
\hline
\end{tabular}

$K m_{\mathrm{A}}, K_{\mathrm{dA}}$ and $\mathrm{I}_{\mathrm{A}}$ denote $K m, K_{\mathrm{d}}$, and $\mathrm{I}_{50}$ for $\mathrm{AChE}$ inhibition in the presence of CE, respectively, of inhibitor A. Similarly, $K m_{\mathrm{B}}, K_{\mathrm{dB}}$ and $I_{\mathrm{B}}$ denote $K m, K_{\mathrm{d}}$ and $\mathrm{I}_{50}$ for AChE inhibition in the presence of $\mathrm{CE}$, respectively, of inhibitor $\mathrm{B}$.

Values given in Tables 1 and 3 were used for computation of these parameters. 
Table 5 Parameters for the evaluation of potentiation level produced by a joint action of malathion (inhibitor A) combined with various other compounds (inhibitor B).

\begin{tabular}{lcccc}
\hline & \multicolumn{3}{c}{ Parameter } \\
\cline { 2 - 4 } Inhibitor & $K m_{\mathrm{A}} \mathrm{I}_{\mathrm{B}} / \mathrm{I}_{\mathrm{A}}$ & $K m_{\mathrm{B}} / q$ & $K_{\mathrm{dA}} \mathrm{I}_{\mathrm{B}} / \mathrm{I}_{\mathrm{A}}$ & $K_{\mathrm{dB}} / r$ \\
\hline Malathion & $19)$ & 1 & 76.6 & 1 \\
Paraoxon & 11.1 & 1.18 & 0.167 & 5.19 \\
Dichlorvos & 0.0241 & 1.21 & 0.591 & 0.499 \\
Carbaryl & 0.0853 & 20.5 & 0.222 & 64.5 \\
Metolcarb & 0.0320 & 22.1 & 1.66 & 24.1 \\
Malaoxon & 0.240 & 42.7 & 5.18 & 15.9 \\
Pirimicarb & 0.748 & 42.9 & 13.0 & 36.3 \\
Propoxur & 1.88 & 170 & 0.0949 & 215 \\
Methomyl & 0.0137 & 1800 & 2.37 & 380
\end{tabular}

$K m_{\mathrm{A}}, K_{\mathrm{dA}}$ and $\mathrm{I}_{\mathrm{A}}$ denote $K m, K_{\mathrm{d}}$ and $\mathrm{I}_{50}$ for $\mathrm{AChE}$ inhibition in the presence of CE, respectively, of inhibitor A. Similarly, $K m_{\mathrm{B}}, \mathrm{K}_{\mathrm{d} \mathrm{B}}$ and $\mathrm{I}_{50}$ denote $\mathrm{Km}, K_{\mathrm{d}}$ and $\mathrm{I}_{50}$ for AChE inhibition in the presence of $\mathrm{CE}$, respectively, of inhibitor $\mathrm{B}$.

Values given in Tables 1 and 3 were used for computation of these parameters.

\section{ことが容易に予測される.}

Table 4 と执いて相乗作用が予測されたマラオクソン とジクロルボス，およびマラオクソンとパラオクソンの 組合せを用いて協力係数に与える混合比の影響を調べた 結果は, 拈の扮の Table 6 と Table 7 に示した. なお相 乗作用の予測されたマラオクンンとマラチオンの組合せ については, どちらの阻害剤も $V$ が大きく, $V_{\mathrm{B}} \ll V_{\mathrm{A}} \mathrm{I}_{\mathrm{B}} /$ $\mathrm{I}_{\mathrm{A}}$ の条件を満たすかどらか不明であったので，この組合 せについてはとくに調べなかった．相乗作用の大きさは 協力係数 ${ }^{10)}$ を用いて比較した. 前報 ${ }^{2)}$ で述べた理論的解 析の結果によれば，最も相乗作用の大きくなる混合比は 解毒酵素存在下に批弾独処理での $I_{50}$ の比, すなわ ち $\mathrm{I}_{\mathrm{A}}$ と $\mathrm{I}_{\mathrm{B}}$ の比に等しくなるが， $\mathrm{I}_{\mathrm{A}}$ と $\mathrm{I}_{\mathrm{B}}$ の比はマラオ クソンとジクロルボスの混合で 1:0.11, マラオクソンと パラオクソンの混合で $1: 3.2 \times 10^{-2}$ である (Table 3). 実 際の実験結果に执いて最も大きな協力係数を与えた混合 比は，マラオクソンとジクロルボスを混合した場合は 1:0.1 (Table 6), マラオクソンとパラオクソンを混合し た場合は $1: 5.7 \times 10^{-2}$ (Table 7) となり, 理論值に最も 近い混合比で, 最も大きな相乗作用が認められた.

以上の上うに最も協力係数の大きくなる混合比は $\mathrm{I}_{\mathrm{A}}$ と $\mathrm{I}_{\mathrm{B}}$ の比に等しいことが実験的に証明されたので， 、 ラオクソン（薬剤 $\mathrm{A} ）$ と連の阻害剤（薬剤 $\mathrm{B}$ )を $\mathrm{I}_{A}$ と $\mathrm{I}_{\mathrm{B}}$ の比と等しくなるょうに混合し協力係数を求めた (Table 8). 協力係数はパラオクソン, ジクロルボス, マラチオン, ピリミカルブの順で大きく他の阻害㓮がこ れに続いた. 協力係数はこの場合 $K m_{\mathrm{B}} / q$ 之 $K_{\mathrm{d}_{\mathrm{B}}} / r$ の值
Table 6 Effect of the mixing ratio of malaoxon and dichlorvos on co-toxicity coefficient calculated from $I_{50}$ for AChE inhibition in the presence of $\mathrm{CE}$.

\begin{tabular}{|c|c|c|c|}
\hline \multicolumn{2}{|c|}{ Ratio } & \multirow{2}{*}{$\begin{array}{l}\left.\mathrm{I}_{50}{ }^{\mathrm{a}}\right) \\
(\mu \mathrm{M})\end{array}$} & \multirow{2}{*}{$\begin{array}{l}\text { Co-toxicity } \\
\text { coefficient }\end{array}$} \\
\hline Malaoxon & Dichlorvos & & \\
\hline 1 & 0.01 & 13.9 & 172 \\
\hline 1 & 0.1 & 4.37 & 345 \\
\hline 1 & 1 & 1.75 & 301 \\
\hline 1 & : 10 & 1.92 & 166 \\
\hline
\end{tabular}

a) Data expressed as the sum of both inhibitors.

Table 7 Effect of the mixing ratio of malaoxon and paraoxon on the co-toxicity coefficient calculated from $I_{50}$ for AChE inhibition in the presence of $\mathrm{CE}$.

\begin{tabular}{|c|c|c|c|}
\hline \multicolumn{2}{|r|}{ Ratio } & \multirow{2}{*}{$\begin{array}{l}\mathrm{I}_{50}{ }^{\mathrm{a})} \\
(\mu \mathrm{M})\end{array}$} & \multirow{2}{*}{$\begin{array}{l}\text { Co-toxicity } \\
\text { coefficient }\end{array}$} \\
\hline Malaoxon & Paraoxon & & \\
\hline 1 & $5.7 \times 10^{-4}$ & 12.7 & 198 \\
\hline 1 & $5.7 \times 10^{-3}$ & 6.24 & 352 \\
\hline 1 & $5.7 \times 10^{-2}$ & 1.85 & 529 \\
\hline 1 & $5.7 \times 10^{-1}$ & 0.660 & 326 \\
\hline
\end{tabular}

a) Data expressed as the sum of both inhibitors.

(Table 4) が小さくなるほど大きくなると予想される が，マラオクソンとマラチオンの組合せは，マラオクソ ンをジクロルボスやパラオクンンと組み合わせた場合よ 
Table $8 \quad \mathrm{I}_{50}$ and co-toxicity coefficient for AChE inhibition determined in the presence of $\mathrm{CE}$ in various combinations of malaoxon (inhibitor A) and other inhibitors (inhibitor B) which were mixed at a ratio designated in the table.

\begin{tabular}{lccc}
\hline Inhibitor B & Ratio $^{\mathrm{a})}$ & $\left.\mathrm{I}_{50}(\mu \mathrm{M})^{\mathrm{b}}\right)$ & $\begin{array}{c}\text { Co-toxicity } \\
\text { coefficient }\end{array}$ \\
\hline Malathion & 14.8 & 61.7 & 329 \\
Paraoxon & 0.0322 & 2.30 & 577 \\
Dichlorvo3 & 0.114 & 2.74 & 523 \\
Carbaryl & 0.0428 & 8.51 & 158 \\
Metolcarb & 0.321 & 14.1 & 120 \\
Pirimicarb & 2.52 & 14.0 & 323 \\
Propoxur & 0.0183 & 6.03 & 217 \\
Methomyl & 0.00984 & 10.5 & 124 \\
\hline
\end{tabular}

a) $\mathrm{I}_{50}$ of inhibitor $\mathrm{B} / \mathrm{I}_{50}$ of inhibitor $\mathrm{A}$.

b) Data expressed as the sum of inhibitors $\mathrm{A}$ and $B$.

りも協力係数が小さかった. この結果はマラオクンンと 同様にマラチオンの分解活性も高いことから，おそらく マラオクソン（薬剤 A） とマラチオン（薬剤B）を組み 合わせた場合の $V_{\mathrm{B}} /\left(V_{\mathrm{A}} \mathrm{I}_{\mathrm{B}} / \mathrm{I}_{\mathrm{A}}\right)$ はマラオクソンをジクロ ルボスやパラオクソンと組み合わせた場合よりも大きく なるからだと考えられる。

前報 ${ }^{2)}$ で示した理論的解析による結論, すなわち, 相 乗作用は各薬剂の解毒酵素に対する親和性, 解毒速度お よび解毒酵素の存在下での作用点阻害の $I_{50}$ によって子 測できるといらこと, また相乗作用の最も大きくなる混 合比は $I_{50}$ の比と等しいことは以上の結果によって支持 された. 本研究の結果から, 殺虫剤どらしの組合せにお いて, 相乗作用の機構が解毒酵素の阻害に基づく場合の 薬剤 A（解毒を阻害される測）と薬剤 B（解毒を阻害す る側）の特徵を明確に示すことができる.すなわち, 薬 剤 A（たとえばマラオクソン）は作用点に対する阻害能 力が大きいこと, 解毒されやすいこと, および解毒酵素 に対する親和性の小さい薬剤である，薬剤 B（たとえば ジクロルボスとパラオクソン）は解毒酵素に対する親和 性が高く, 作用点を阻害するよりも低濃度で薬剤 A の解 毒を阻害できる薬剤といえる，著者らは以上のような結 論に基ついて，すでにダイアジノン抵抗性のイェバェに
対してきわめて高い相乗作用を示す薬剤の組合せを見つ けており，その相乗作用の機構は以上のような結論によ って説明可能であることを明らかにしている ${ }^{11)}$.

\section{摘要}

殺虫剤の相乗作用の大きさはおのおのの薬剤の解毒酵 素に対する親和性, 解毒速度および解毒酵素の存在下で の作用点阻害の $I_{50}$ 值によって予測できるという理論的 解析の結果 ${ }^{2}$ を証明するために, in vitro 実験を行なっ た. 単一の酵素（ブタ肝カルボキシルェステラーゼ）

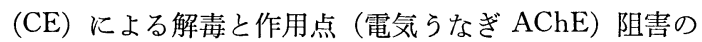
みが含をれる単純なモデルを用いて，相乗作用の予測に 必要な各パラメータを求めたところ, マラオクソンとパ ラオクソンおよびマラオクソンとジクロルボスの組合せ が最も相乗作用の条件を満たしていた. 各種組合せによ る AChE 阻害の $I_{50}$ を比較したところ, 上記の組合せ は実際に高い相乗作用を示し, また，相乗作用の最も大 きくなる混合比は薬剤単独での $I_{50}$ の比に等しかった. 以上の結果はュンピュータシミュレーションによる理論 的解析の結果 ${ }^{2)}$ を支持した.

\section{引用 文 献}

1）酒井清六：殺虫剤の連合作用に関する昆虫毒物学 的研究，八州化学工業株式会社, 1960

2) 大井正典・本山直樹：農薬誌 16，465（1991）

3) 大井正典 - W. C. Dauterman - 本山直樹：農薬誌 16, 257 (1991)

4) T. Nishioka, K. Kitamura, T. Fujita \& M. Nakajima: Pestic. Biochem. Physiol. 6, 320 (1976)

5) A. R. Main \& W. C. Dauterman: Nature 198, 551 (1963)

6) M. L. Bender, F. C. Kézdy \& F. C. Wedler: J. Chem. Education 44, 84 (1967)

7) P. T. Lin, A. R. Main, W. P. Tucker, N. Motoyama \& W. C. Dauterman: Pestic. Biochem. Physiol. 21, 223 (1984)

8) W. N. Aldridge: Biochem. J. 46, 451 (1950)

9) 本山直樹：薬物抵抗性, 深見順一 一上杉康彦・石 塚皓造編，ソフトサイエンス社, pp. 54-85 (1983)

10) Y. P. Sun \& E. R. Johnson: J. Econ. Entomol. 53, 887 (1960)

11）大井正典・本山直樹：応動昆 35，231（1991） 